\title{
Global Financial System Outcomes after 2008: A Longitudinal Comparison
}

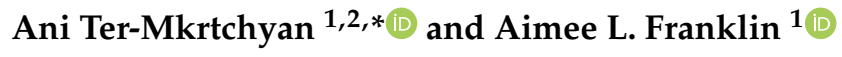 \\ 1 Department of Political Science, University of Oklahoma, Norman, OK 73019, USA; alfranklin@ou.edu \\ 2 National Institute for Risk and Resilience, University of Oklahoma, Norman, OK 73019, USA \\ * Correspondence: anitm@ou.edu
}

Received: 2 September 2019; Accepted: 19 March 2020; Published: 24 March 2020

check for updates

\begin{abstract}
This paper examines how the governance context and financial institutions may relate to different aspects of a country's financial system before and after a crisis. Using a fixed-effects regression model for panel data and a comparative perspective, we assess longitudinal trends in the functioning of the financial systems. This modeling allows us to explore how the level of development of 139 countries and conditions related to political stability, regulatory quality, and the rule of law, may have influenced financial system outcomes. We measure financial system outcomes across four dimensions: financial depth, efficiency, stability, and access. Our findings suggest that the explanatory variables had limited statistical significance on the proxy measures of financial system outcomes. Furthermore, the relationships were not consistent across all financial system outcome variables. These results suggest that political stability and the rule of law do influence depth and efficiency, respectively, as proxy indicators of financial system outcomes.
\end{abstract}

Keywords: financial system outcomes; institutions; central bank; transition economies; governance; regulation

JEL Classification: E5; E6; H3; H5

\section{Introduction}

At the time it occurred, much was written about the magnitude of the 2008 financial crisis and the expectations about how long the recovery would take if one were even possible. While there continues to be great debates about what may have caused the crisis (Lo 2012), there is a lack of understanding about the role of perceptions related to financial system outcomes. In this study, we seek to improve our knowledge by testing the explanatory power of perceptions of government's actions as they represent the governance context for financial system outcomes. ${ }^{1}$ Also, we use a comparative longitudinal approach to assess whether the performance of financial system outputs is a function of the level of economic development of the countries.

The governance context is vital for creating opportunities or imposing constraints on financial system development and outcomes. Most nations have created organizations featuring political officials making policy decisions, central banks administering regulations, and the courts which enforce

1 Johns defines context as "situational opportunities and constraints that affect the occurrence and meaning of organizational behavior as well as functional relationships between variables" (Johns 2006, p. 386). We differentiate the term context from the term institutions, which are the formal or informal rules of the game in a society that governs or constrains human [and organizational] interactions (North 1981, pp. 3, 201-2). In this paper, we use operating or governance context to refer to the private and government actors and organizations that play a role in the financial system. Institutions are the rules that all financial system actors must follow. 
the rule of law. Each of these organizations is tasked with an administrative role in assuring financial system stability. Political officials are expected to pursue the policies favored by their parties without unduly disrupting the operations of financial markets. While regulatory agencies, like central banks and the courts, are designed to be politically independent, the role each plays in the governance systems of a country may influence the trajectory of financial system outcomes, which in turn can influence socio-economic conditions and the degree of democratization (Lijphart 2012; North and Thomas 1973; North 1990).

The governance context, in its turn, is interdependent with the financial market context. It has been well established that financial system participants, such as banks, insurance companies, and financial intermediaries, can play a vital role in poverty alleviation, economic development, and the economic stability of the country (Levine 2005). Regulation has costs and benefits. The executive branch of government makes sure that the regulators balance the benefits and the costs of enacted regulation (Hahn and Sunstein 2002). This, of course, is no easy task when multiple public and private organizations are involved (Ansell and Gash 2008; U.S. Department of the Treasury 2017). When this occurs, incentives are created for a sufficient number of financial intermediaries to offer services in financial systems (Bacchiega and Borzaga 2001; Stringham 2002, 2003; Wakita 2001). This policy context provides an ideal background for our analysis, in which we answer the following research questions:

(1) How do perceptions of the government organizations and the governance context influence the functioning and evolution of financial system outcomes?

(2) How does the level of development of a country influence the functioning and evolution of financial system outcomes?

To answer these questions, we leverage political science/public policy, and institutional economics literature to construct hypotheses regarding the influence of perceptions of political stability, regulatory quality, and the rule of law on financial system outcomes. We also explore the impact of the level of development of the country on the rate of recovery and the performance of financial system stability outcomes across 139 nations. Our findings reveal that from the explanatory variables, the political stability and the rule of law influence depth and efficiency as proxy indicators of financial system outcomes. Our analysis has implications for political science/public policy, and institutional economics, scholars, and practitioners.

In the next section, we provide the conceptual framework for our study and present the hypotheses we use for empirical testing. After that, we describe the data sources and analytical methodology. After analyzing the extent to which the governance context and the level of development influence financial system outcomes across countries, we discuss the findings and implications of our study.

\section{Conceptual Framework}

For financial systems to be sustainable, a collaboration between government and industry is necessary. This collaboration requires each to adopt a hybrid institutional logic where the competitive nature of the market, as well as social responsibility for financial system stability, is recognized by all actors involved in a country's financial system (such as banks, financial services providers, investors, lenders, government, and government-sponsored enterprises, etc.). The adoption of hybrid institutional logics encourages both public and private organizations to consider social goals alongside economic goals. This can be an essential consideration for financial intermediaries wishing to maintain their sustainability in a highly regulated industry since the regulations also must balance economic and social goals (Battilana and Dorado 2010). In the first part of this section, we contextualize our analysis around the great recession of 2008 and how the financial system effects were expected to be long-lasting over time and to dampen the financial market recovery. In the second section, we describe factors that could be expected to influence financial system outcomes. 


\subsection{The Great Recession and the Relative Speed of Recovery}

The world is shrinking: adverse events in one country often diffuse to people and organizations in other countries until they are felt across the globe. This was the case in 2008 when the major financial crisis in the U.S. financial market sent shock waves to financial markets around the world. When events like these occur, it is natural for citizens to expect the government to intervene as a problem solver (De Souza Briggs 2008). However, the government cannot be the sole problem solver-there are advantages to collaboration when markets are already functioning. Furthermore, private organizations and other actors have a shared interest in financial system outcomes that influence their bottom line (Landow and Ebdon 2012).

When events with global repercussions cause financial market adjustments, it would be desirable for the financial system to have sufficient stability to avoid deep shocks and to foster a relatively quick return to equilibrium and steady recovery. Immediately following the systemic shock, political and financial system actors should collaborate to determine what public policies and financial institutions may have contributed to the adjustment, such as government failure caused by regulatory capture (Admati and Hellwig 2013; Admati et al. 2014; Heclo 1987). More importantly, these actors should consider appropriate actions to avoid further downward market tendencies. However, any government intervention, whether it be via fiscal, economic, or monetary policy, or through the adoption of things like automatic fiscal stabilizers (Boushey et al. 2019), needs to be carefully balanced to avoid actions that cause financial markets to expand too quickly and risk inflationary pressures.

Recent institutional economics literature can guide financial system outcomes (Brown et al. 2017). For example, Acemoglu and Johnson (2005) study specific contracting rights on stock market development and credit markets. They find that property rights matter for financial development and growth, while contracting rights are associated only with financial development. In addition, Brown et al. $(2013,2017)$ suggest as well that contracting rights do matter because equity markets fund innovation better than debt does, since, except for patents, you cannot use ideas as collateral for a bank loan. This paper avoids this specific debate, seeking instead to contribute to our understanding of how governance context and mechanisms (Fabozzi et al. 2012), organizations, and institutions affect financial systems outcomes.

\subsection{Sustainability of Financial System Outcomes}

Financial systems facilitate exchanges of funds between investors, savers, lenders, and borrowers. Well-functioning financial systems encourage perfect market conditions, where there is an adequate number of buyers and sellers who can agree upon a fair price. Robust financial systems promote economic growth through a structure that facilitates the intermediation of funds, the smooth transfer of payments, and the management of risks.

The functioning of the financial system is measured across four dimensions: financial depth, efficiency, stability, and access (Čihák et al. 2012; Melecky and Podpiera 2018). These four metrics developed by Maimbo and Melecky (2014) are commonly used to assess financial system outcomes.

Depth " ... is not a function in itself, but is a proxy of the overall extent of services provided by the financial system". (Čihák et al. 2012, p. 8). When financial systems are vast and include many providers of financial products, the market is more competitive, and the prospects for long-term economic growth are improved (Demirgüç-Kunt and Levine 2008). Increased reliance on central bank deposits and debt for state-owned enterprises reduces the competitiveness of the market and may dampen the prospect for economic growth.

Efficiency examines how well financial organizations intermediate resources and facilitate financial transactions for the smooth flow of funds between savers and investors. When this happens, the transaction costs are lower, and markets are high functioning without intervention by the government or the central bank.

Stability suggests that financial systems have low levels of vulnerabilities that reduce market functioning. Furthermore, stable markets are resilient and can quickly adapt to changes in markets, 
economic conditions, or episodes of systemic stress. Stable financial systems require less governmental policy intervention or regulation in both the short- and long-terms.

Access (inclusion) is the degree to which individuals can and do use financial services. Having greater access means that the financial market is competitive, and savings rates will be higher while lending rates will be lower. Government organizations can facilitate access to markets. In the United States, the U.S. Federal Deposit Insurance Corporation (FDIC) facilitates access to markets by providing deposit insurance whereas the publicly traded U.S. Federal National Mortgage Association (FNMA) guarantees mortgages through government-sponsored enterprises.

\subsection{Factors Influencing Financial System Outcomes}

The importance of the organizational context on performance indicators has long been established in neoclassical organizational theory. Scholars in this field explain that organizations do not, and could not, exist as isolated islands (Hannan and Freeman 1989; Katz and Kahn 1966). Scholars should take into account the external factors of the organizations that can influence their success (Pfeffer and Salancik 1978; Thompson 1967). Empirical research has supported the claim that organizations, as open systems, are embedded in the broader system and are interdependent on the dynamics of the operating context (Scott 2003). Organizations gain social support and legitimacy from external actors and other organizations (Hannan and Freeman 1989; Scott 2003), and performance results are based on those interdependencies (Scott 2003).

Time is an essential variable in our analytical framework. Pierson (2004) argued for the role of path dependence and friction on policy change. Path dependence assumes that the past is reflected in the present. This reflection is expressed both through political institutions, as well as in particular policies that reform government (Pierson 2004). Because of path dependence, reforms are hard to implement: political institutions tend to return to their "normal" past condition in an attempt to ensure stability (Pierson 2004). In this regard, we are interested in examining the patterns of performance for financial system outcomes during a 13-year time frame centered around a global financial market adjustment. To get a better understanding of the trends, we explore the extent to which the governance context influences financial system outcomes over time.

It has been well established in business administration literature that external factors such as competition with other firms, the regulatory framework, and more impact organizational development strategy (Voiculet et al. 2010), organizational stability (Zinovieva et al. 2016), management of change (Hassin 2010), and other performance-related outcomes (Gupta 2013). Studies emphasizing the operating context in the political science and public policy literature have mostly emerged in the 21st century and have been influenced by organization theory. O'Toole and Meier underscore the importance of "context" in public policy research (O'Toole and Meier 2015, p. 238). As Norton Long (1949) described, power is the lifeblood of administration. Our independent variables are drawn from this literature to measure whether the financial system operating contexts are proxies for the governance context. In the sections below, we present the conceptual and operational definitions of each of our explanatory variables.

\section{a. Political Stability}

By drawing from political science literature, we conceptualize that the external political climate in a country creates opportunities and constraints for the creation of public value or production of any outcomes, including financial system outcomes ( $\mathrm{O}^{\prime}$ Toole and Meier 2015). Following this logic, we claim that the stability of the operating context may influence financial system outcomes. As noted by Song and Thakor, " ... politicians determine the nature of political intervention designed to expand credit availability ... (Song and Thakor 2012, p. 491). While financial access is important for competitive financial system " ... political intervention results in an increase in financial system risk." (Song and Thakor 2012, p. 491). Central banks have government-authorized financial tools to reduce financial risk and ensure financial system stability. While many regulatory organizations are 
politically independent, it can be informative to study how the functioning and financial development is associated with the financial system's operating context from a comparative perspective (Cama and Pittaluga 1999; Mishkin and Eakins 2012). To do this, we use a measure of the perceptions of likelihood of political stability (Kaufmann et al. 2010).

Hypothesis 1 (H1): Positive perceptions of political stability, will foster more competitive financial system outcomes.

\section{b. Regulatory Quality}

While political context is essential for creating opportunities and constraints for financial development, institutional economists also emphasize the importance of regulatory quality in financial system outcomes (North and Thomas 1973; North 1990). The government is involved in the financial markets through the formulation and implementation of policies and regulations that promote a properly functioning market, which will prominently feature private sector development. There are two primary ways that governments can intervene in financial systems. Each of these alters one or more of the dimensions of a stable financial system. When the government intervenes through market regulation, transaction costs increase, meaning depth and access can be reduced. When the government intervenes through market manipulation via monetary, economic, or fiscal policy, the efficiency of the market is threatened by the presence of additional transaction costs. Therefore, the role of government in financial system functioning should include consideration of the activities of the central bank and state-owned enterprises as well as the policies and rules that govern financial transactions.

We examine the relationship between the governance context and institutional arrangements a country has put in place that relates the quality of financial market regulation to financial system outcomes. Regulatory quality was operationalized as the perceptions of the ability of government to formulate and implement sound policies and regulations that permit and promote private sector development (Kaufmann et al. 2010).

Hypothesis 2 (H2): Positive perceptions of regulatory quality will foster more competitive financial system outcomes.

\section{c. Rule of Law}

Many nations rely on central banks to oversee the monetary system and to achieve desired financial system outcomes. It has been well established that financial organizations, such as banks and insurance companies, together with financial markets, play a vital role in poverty alleviation, economic development, and economic stability of a country (Levine 2005). However, the functioning of these organizations is determined by the rules and governance structures of the country. The third factor that may influence financial system outcomes is governance structures. Predictability in the rules associated with transactions and security in the ownership of assets is key to fostering well-functioning markets. This is especially true in the areas of contract enforcement and property rights when financial assets are involved. When financial intermediaries, especially investors, savers, lenders, and borrowers, have confidence in and abide by the rules of society as they are carried out by a highly functional judicial system, then financial system outcomes should be stronger. We operationalize the rule of law as the perceptions of the extent to which people have confidence in and abide by the rules of the society (Kaufmann et al. 2010).

Hypothesis 3 (H3): Positive perceptions of the rule of law will foster more competitive financial system outcomes.

\section{d. Level of Development}

Central banks facilitate the functioning of financial intermediaries described above, as mega regulators in some countries or as regulatory commissions in others (Cecchetti and Schoenholtz 2011; 
Sikken and Haan 1998). For instance, the central banks in countries with less sustainable democracies, like Turkey or the Eastern European states, are not only concerned with monetary and financial stability and regulating market functions but also with the provision of other public goods, like debt and asset management. Whereas in more developed countries, these functions have historically been diverted to other organizations in the public or private sector (Ter-Mkrtchyan 2018).

Therefore, in our study, we assess how trends in financial system outcomes may have been developed differently based on the underlying economic country conditions as represented by the category for the level of development (developing, transition, and developed) to see if there are comparative differences across time.

Hypothesis 4 (H4): Countries with developed economies will foster the most competitive financial systems outcomes, followed by transition and developing economies.

\section{Methodology}

Using panel data for 139 countries between the years 2002 and 2014, we tested ordinary least squares (hereafter OLS) regression models with country and time fixed effects with standard errors clustered by country using four proxy indicators for financial system outcomes. These models include independent variables for the influence of economic (level of development), political, regulatory, and legal factors.

Three data sources were used in this analysis. Data Source \#1. To measure the financial system outcomes, we use the World Bank's Global Financial Development Database (World Bank 2018). This database attempts to provide empirical shape and substance to the complex, multifaceted, and sometimes amorphous concept of the functioning of financial systems and to encourage the examination of cross-country systems at a moment in time and across time. This is an extensive dataset of financial system characteristics for 215 countries from 1960 to 2017 (World Bank 2018). Of this number, countries were eliminated from the population data set if more than five data points were missing for any variable in the model. The remaining dataset included 139 of the 215 original countries.

The database includes 15 measures of depth, meaning the size of financial institutions and markets, 11 measures of the efficiency of financial intermediaries and markets; eight measures of the stability as proxies for a country's financial system stability and 40 measures of access, meaning the degree to which individuals can and do use financial services (World Bank 2018). We use one measure from each of the four dimensions to assess financial system outcomes between 2002 and 2014, which includes the 2008 financial crisis. Table 1 presents these variables.

Table 1. Measure of Financial System Outcomes.

\begin{tabular}{cl}
\hline \multicolumn{1}{c}{ Variable } & \multicolumn{1}{c}{ Definition } \\
\hline Depth [DI.06] & $\begin{array}{l}\text { The ratio of central bank assets to GDP. Central bank assets are claims on the } \\
\text { domestic real nonfinancial sector rather than private credit. Measured as a \%. } \\
\text { A lower score reflects lower government claims and a more sustainable financial } \\
\text { system outcomes. }\end{array}$ \\
\hline Efficiency [EI.08] & $\begin{array}{l}\text { Credit to government and state-owned enterprises to GDP. Measured as a \%. } \\
\text { A lower score reflects less monetary intervention by the government and more } \\
\text { sustainable financial system outcomes. }\end{array}$ \\
\hline Stability [SI.01] & $\begin{array}{l}\text { Bank z-score captures the probability of default of a country's commercial banking } \\
\text { system. Measured as a \%. A higher score reflects a decreased likelihood of default } \\
\text { and might result in a more sustainable financial system. }\end{array}$ \\
\hline & $\begin{array}{l}\text { A measure of the degree of competition based on profit-efficiency. It is calculated as } \\
\text { the elasticity of banking profits to marginal costs. An increase in the Boone } \\
\text { indicator implies a deterioration of the competitive conduct of financial } \\
\text { intermediaries. Measured as a \%. A lower score reflects more sustainable financial } \\
\text { system outcomes. }\end{array}$ \\
\hline
\end{tabular}


Data Source \#2. The status of a country's level of economic development was drawn from the 2014 United Nations report titled: World Economic Situation and Prospects (WESP) (United Nations 2014). The variable for development was coded ordinally using these categories: developing economies $(n=91)$, economies in transition $(n=15)$, and developed economies $(n=32)$, labeled 1,2 , and 3 , respectively (United Nations 2014).

Data Source \#3: To assess the relationship of organizational context to financial system outcomes, we use data from the World Bank's Worldwide Governance Indicators (WGI) (World Bank Group 2019). This database contains aggregate and individual governance indicators for over 200 countries and territories over the period 1996-2017 across six dimensions of governance (World Bank Group 2019).

From the WGI database, we use the measures of perceptions of political stability, regulatory quality, and the rule of law as proxy measures for the country's governance context and the organizations tasked with carrying out political and social institutions (World Bank Group 2019). In our data set, the nations are ranked ordered from the worst perceptions (0) to the best perceptions (100) when compared to other countries in the data set. Table 2 presents the definitions of the explanatory variables.

Table 2. Governance Context and Organizations Measures.

\begin{tabular}{cl}
\hline \multicolumn{1}{c}{ Variable } & \multicolumn{1}{c}{ Definition } \\
\hline Political Stability ${ }^{1}$ & Reflects perceptions of the likelihood of political stability. \\
\hline Regulatory Quality & $\begin{array}{l}\text { Reflects perceptions of the ability of the government to formulate and implement } \\
\text { sound policies and regulations that permit and promote private sector } \\
\text { development. }\end{array}$ \\
\hline Rule of Law & $\begin{array}{l}\text { Reflects perceptions of the extent to which people have confidence in and abide by } \\
\text { the rules of society, and in particular the quality of contract enforcement, property } \\
\text { rights, the police, and the courts, as well as the likelihood of crime and violence. }\end{array}$ \\
\hline $\begin{array}{l}1 \text { These definitions are simplified from the WGI variable definitions. In the WGI study, the definition for the variable } \\
\text { describes perceptions of the likelihood of political instability or politically motivated violence, including terrorism. } \\
\text { The variable's values are coded so that high rankings translate to strong political stability and a low perceived } \\
\text { likelihood of politically motivated violence. }\end{array}$
\end{tabular}

Table 3 provides descriptive statistics of the variables used in the analysis. For the explanatory variables, each of the 210 countries in the original data set was ranked comparatively. The country with the highest relative score was assigned a value of 100, and the lowest-scoring country was assigned a value of 0 . Therefore, the standard deviations are not unusual. The minimum value of 0.47 reflects the removal of countries with the lowest values due to missing data.

Table 3. Descriptive Statistics.

\begin{tabular}{|c|c|c|c|c|c|c|c|c|c|c|}
\hline \multirow{2}{*}{ Variable } & \multicolumn{2}{|c|}{$\mathrm{n}$} & \multirow{2}{*}{ Mean } & \multirow{2}{*}{ Median } & \multirow{2}{*}{$\begin{array}{c}\text { Mode } \\
a=\text { multiple }\end{array}$} & \multirow{2}{*}{ SD } & \multirow{2}{*}{ Skew } & \multirow{2}{*}{ Kurt } & \multirow{2}{*}{ Min } & \multirow{2}{*}{ Max } \\
\hline & Valid & Missing & & & & & & & & \\
\hline Political Stability & 1739 & 1 & 47.35 & 45.23 & $0.95^{\mathrm{a}}$ & 27.6 & 0.15 & -1.11 & 0.47 & 100 \\
\hline Rule of Law & 1794 & 0 & 49.99 & 47.47 & 100.00 & 27.9 & 0.17 & -1.08 & 0.47 & 100 \\
\hline Depth & 1779 & 15 & 4.40 & 2.25 & $0.01^{\mathrm{a}}$ & 6.2 & 3.44 & 18.04 & 0.00 & 59.65 \\
\hline Stability & 1786 & 8 & 13.64 & 12.10 & 15.00 & 8.8 & 2.19 & 6.812 & -0.24 & 64.43 \\
\hline Access & 1761 & 33 & -0.09 & -0.06 & 0.00 & 2.0 & -23.56 & 734.68 & -59.82 & 11.34 \\
\hline
\end{tabular}

The most crucial concern with the descriptive statistics in Table 3 is the distributions of the four measures of financial system outcomes. For the measures of depth and access, the distribution was highly skewed and leptokurtic (kurtosis above 3). This reflects the uneven distribution of countries across the development index. While this is not the case for efficiency, the four variables were transformed using Log10 and the non-directional two-way statistical test results are reported. 


\section{Results}

We first present a visual examination of financial system outcomes over time. As shown in Figure 1, the effects of the financial market crisis appear to be felt in financial system outcomes worldwide. However, the financial systems were generally able to respond appropriately and regain equilibrium across most indicators.

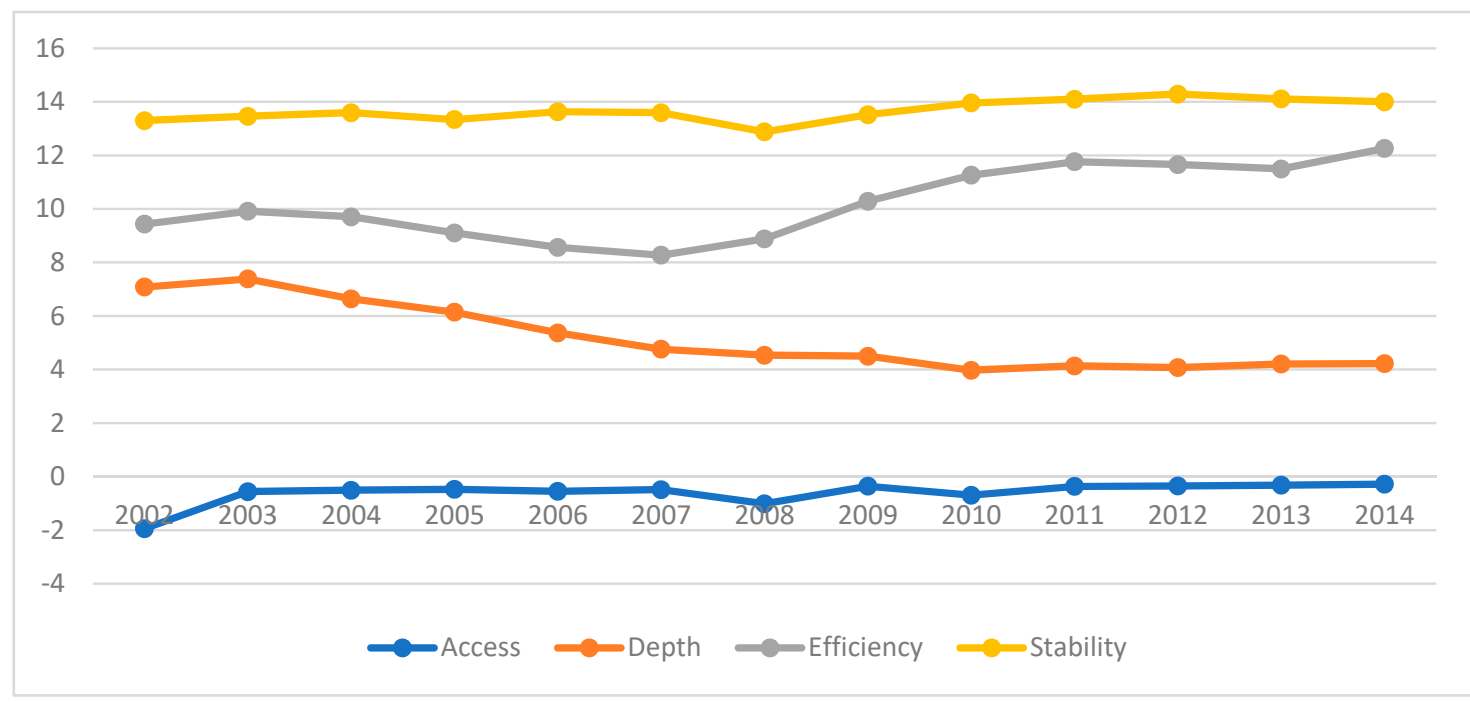

Figure 1. Longitudinal Financial System Stability Outcomes Worldwide. Note: Per each dimension, average measures are aggregated for all countries. One country's single year value was so extreme it statistically shifted the trend line in 2002 when compared to other years.

In particular, looking at the trends for each outcome, we can see a downward trajectory for depth from 2002 to 2008. There was also no noticeable adjustment in 2008. A continued downward, although moderated trajectory post-2008 suggests less government reliance. ${ }^{2}$

The trajectory for the measure of efficiency increases sharply in the period between 2009 and 2014 and is markedly different from the 2002-2008 trajectory. This measures the amount of credit provided to the government as a ratio of GDP. As such, it reflects two realities of a financial crisis. First, the government, via the central bank, must play an intervention role in stabilizing the economy. Second, the gross domestic product will be impacted by the financial crisis. In this case, it appears that the impacts of the financial crisis were more long-lasting for efficiency than for other financial system outcomes. The measure of stability shows a slight dip in 2008, as would be expected. However, equilibrium is quickly regained, and the stability of outcomes remains through 2014 . This suggests that financial systems have adequate controls to keep the probability of banking system default in a very narrow range. The drop in the level of access in 2008 is expected, since a financial crisis will reduce the number of actors involved in a country's financial system, thus increasing competition. However, the effects were limited to the short term, with the trajectory returning to pre-2008 levels and remaining stable through 2014 . It is encouraging to notice from this trend line that the adjustment was relatively minor.

For inferential results, our hypotheses are tested using panel data with time and country fixed effects and standard errors clustered by country in OLS regression models presented in Table A1 in Appendix A. The explanatory variables are reported at the time " $t-1$, , and the impact of the dependent variables are present in time $t^{3}$. To test the effect of the level of economic development,

2 The distributions for the four dependent variables are not bimodal.

3 We tested the model for five years after the financial crisis. We do not report the results for $\mathrm{t} 2-\mathrm{t} 5$ since only $\mathrm{two}$ models have statistically significant findings in the expected direction over from $\mathrm{t} 2 \mathrm{t} \mathrm{t}$. These are for Depth DV: Political Stability, 
the developing economies are the omitted category, and dummies are reported for transition and developing economies.

A few general conclusions about the four models can be made. Political stability or the rule of law are influential in all the models. The level of development matters for all proxy measures of financial system stability outcomes, with the exception of depth. However, the results for these explanatory variables are not consistent across the models. In many cases, the direction of the relationship was not as expected, irrespective of whether or not statistical significance was achieved for a specific independent and dependent variable combination.

The model for depth has explanatory power in the expected direction from the political stability variable. Regulatory quality has the predicted direction, but no statistical significance. Whereas, the transition and developed economy levels were statistically significant but in the opposite direction.

For the model of efficiency, political stability and transition economies were statistically significant and in the expected direction. The relationship between developed economies and efficiency was not significant but was in the predicted direction. The variables for regulatory quality and the rule of law were neither significant nor as expected directionally.

The model testing the financial system outcome stability features developed nations having statistically significant positive relationship with the dependent variable. Transition economies also had statistical significance but in the opposite direction. The relationships with political stability, as well as the rule of law, were in the expected direction but not significant. The regulatory quality variable had neither significance nor an impact in the expected direction.

The explanatory variables in the model for the access dependent variable performed the poorest of all tested. Only transition economies had statistical significance in the predicted direction. Developed economies and the rule of law had an impact in the expected direction but no statistical significance. Political stability and regulatory quality were neither statistically significant nor in the expected direction.

For the first three hypotheses, we explored if financial system outcomes were more or less sustainable based on variations in perceptions about the governance context. For hypothesis \#1, the political stability variable affected all dependent variables in the expected direction in all models except for the dependent variable access. Political stability was statistically significant in the depth and efficiency models. This observed association suggests that political stability has the potential of influencing the competitiveness of financial systems with less government reliance and intervention. Substantively, this association makes sense as outcome measures of stability and access are concerned with the competition between-and the risk of default for-commercial banks.

The influence of regulatory quality in fostering competitive market conditions was explored in hypothesis \#2. None of the dependent variables had statistically significant relationships with regulatory quality, even when delaying the time measurement of the outcome variables. Regulatory quality had no significance in any model and was correctly predicted in only the depth model. This finding could suggest that regulations are generally stable, even in the face of the financial market crisis. In addition, this finding may be explained by the fact that regulatory quality changes slowly and it does not have a strong influence on actors involved in financial systems. Also, this may also signal that changes following the 2008 crisis, such as those adopted in the United States, were perceived as being necessary and deemed appropriate to avoid repeated volatility in financial systems in the future.

Perceptions related to the rule of law were tested in hypothesis \#3. The rule of law variable has no statistically significant relationship in any model. The direction of the relationship is not in the expected direction for depth or efficiency. But the direction of the relationship is as predicted for stability and access. These findings are interesting as they suggest that the rule of law is perceived to

and, for Efficiency DV: Political Stability and Development Level 2. In addition, there were neither statistically significant nor substantive changes present in any of the models following the inclusion of dummy variable interactions between developed and post- 2008 dummy. 
make the likelihood of default smaller, as predicted in existing literature. It is noteworthy that there were no statistically significant relationships between the rule of law and the financial system outcomes of depth and access. Like regulatory quality, the rule of law seldom changes, thus predictability in banking may be more a function of the market than regulations or laws.

These mixed results in both statistical significance and for relationships in the predicted direction in the first three hypotheses confirm the need for assessing the impact of the explanatory variables on multiple dimensions of financial system outcomes since the findings suggest that the influence of the governance context and organizations as well as economic factors have differential effects. The lack of consistent relationship modeling is puzzling. This may signal an additional distinction between perceptions of individuals versus more macro-level variables such as the country's financial institutions and governance context. This might also be explained due to the heterogeneity within and across countries, such that aggregate governance indicators might not have a full explanatory factor to affect individual factors the same way. 4

Hypothesis \#4 was tested using developing economies as the omitted variable. Transition and developed economies were expected to have better results. The statistical results show that transition economies are highly statistically significant in all four models. However, the predicted relationships are as expected in the models for efficiency and access only. The models for depth and stability are not in the expected direction. These findings indicate that the financial systems of these countries may be underrepresented by private credit and at a relatively high risk of banking default. One of the perceived benefits of using central banks as mega-regulators is the ability of the organization to introduce automatic stabilizers into financial systems (Boushey et al. 2019). For these economies, the benefits tend to be found more in the measures of efficiency and access.

The developed economies variable has a significant and positive relationship with stability. In the depth model, the developed economies variable has a statistically significant relationship with the dependent variable, but not in the expected direction. The relationship between developed economies and the efficiency and access measures of financial system outcomes are in the predicted direction but are not statistically significant. This suggests more-rather than less-government intervention, and thus less natural competition in the market. Short-term government intervention in financial systems can be desirable during unfavorable macro-economic conditions; however, there would be a normative desire to curtail this activity over time and shift back to a greater reliance on competitive markets.

\section{Discussion}

This cross-disciplinary research examines financial system stability during growth and volatility surrounding crises. Four factors in existing literature suggest variables that may influence financial system outcomes: perceptions of political stability, regulatory quality, the rule of law, and the level of economic development of the county. Our data includes longitudinal indicators from 139 countries for the period 2002 to 2014, which includes the 2008 global financial crisis. We analyze the differences in the financial system outcomes across four proxy dimensions: depth, efficiency, stability, and access.

We find that across all four proxy dimensions of financial system outcomes, only depth, efficiency, and stability are influenced by political stability as expected. On one hand, this is not surprising since election cycles and staggered terms of representation serve as stabilizers. It appears that there are no commonly held perceptions that political leaders played an influential role (positive or negative) in the economic response to the crisis since there is no evidence of a lagging lack of stability that could be present during the regime change in 2009. Regulatory quality was not significant in any model and had the expected direction only in the depth model.

There were no statistically significant relationships between the rule of law in any model, and the predicted direction of the relationship occurred only in the stability and access models. The level

4 We would like to give credit to our anonymous reviewer for this observation. 
of development of the country with financial system efficiency was significant but in the opposite direction from what we had expected. Our findings suggest that the perceptions of political stability and developing economies had the strongest explanatory power in the predicted direction. The variables the rule of law and the level of development had a predictive power for financial system outcome measure of access in the expected direction. For the measure of access only transition economies had statistically significant relationship. The mixed findings across all four hypotheses might be related to the fact that these four dimensions of financial system outcomes can be idiosyncratically impacted by both governance context as well as financial institutions.

In this study, the choice of the explanatory factors was driven by leveraging political science/public policy and organizational theory literature to explore financial system outcomes driven by hybrid institutional logics and government interdependencies (Battilana and Dorado 2010). While the internal validity of the financial system outcome measures that we used has been challenged, we believe those four dimensions serve us helpful proxy indicators for measuring the overall sustainability of the financial system outcomes (Kaufmann and Kraay 2007). The purpose of the analysis was to test hypotheses regarding the impact of the governance context and the level of development of the country on financial system outcomes. Other factors could be considered in future studies. One possibility is to focus on the influence of geographic regions as cultural collectives rather than individual countries on the sustainability of financial systems outcomes.

The analysis could also be replicated with a more extended time series or with monthly or quarterly data. This would allow for a more meticulous methodological approach, such as time series pattern identification by smoothing or seasonality analysis (Box and Jenkins 1976; Velleman and Hoaglin 1981). However, we tested an up to five year time lag between the explanatory and outcome variables and did not find any patterns or substantive changes in the results. Furthermore, this research does not require an analysis of moving average changes and fluctuations since we do not seek to forecast future outcomes. Instead, we wish to document discrete changes in financial system outcomes in the short-term as well as in the long term following a significant market correction. We recognize the limitation of the inferential power of our models by the choice of OLS regression that represents multi-variate average association between variables. An analysis with experimental design would empower establishing true causality among these variables. In addition, our purpose was to look at these effects comparatively on aggregate. However, in doing so we recognize that the average estimator does not have the power to capture heterogeneity within and across countries.

Nonetheless, knowing more about how the governance context and institutions may relate to different aspects of a country's financial system before and after a crisis informs our understanding of the dynamic relationship between financial market actors and government organizations such as the legislative, executive and judicial functions and the central bank or other independent regulatory bodies to prepare for similar financial crisis responses in the future. Responses have varied dramatically over time. The United States' response to the 2008 financial crisis was the adoption of the American Recovery and Reinvestment Act. Funneling money to infrastructure and contractors in the building sectors was utterly different from the creation of the welfare state in President Roosevelt's New Deal following the Great Depression of 1929. The 2008 response encourages competitive market functioning while the latter requires higher intrusion by the government into financial markets.

The muted impact on financial system outcomes and the relatively rapid return to equilibrium following the 2008 financial crisis stands in stark contrast to the Great Depression. Future research could tease apart the regulatory functions of central banks and their modes of collaboration with financial intermediaries. This may signal more strategic use of hybrid institutional logics where the government cooperates more and deploys levers that benefit market-based organizations, plus private firms take on more responsibility for the social impacts of their actions. Evidence of this would support the strategic advantages of hybrid institutional logics (Tracey et al. 2011). This could help to understand why factors like political stability do not have the expected impact on financial system outcomes and 
allow researchers to explore the extent to which central banks are indeed politically independent from the government of the countries in which they operate.

Our findings offer two main contributions to the political science/public policy, and institutional economics literature. By examining trends in the functioning of financial systems, we gain insight into the variables that tend to support a quick recovery and stability after a financial crisis. Our focus was not on the magnitude of the 2008 financial crisis and the expectations on the length of the possible recovery. In this study, we tested the explanatory power of the governance context on financial system outcomes. Second, isolating the level of development reveals that transition economies have different recovery trajectories than developing and developed economies. This warrants future research into the role of central banks to see how they may encourage stabilizing regimes in transition economies.

Author Contributions: The authors contributed equally to this work. All authors have read and agreed to the published version of the manuscript. The authors are grateful to the anonymous reviewers for their suggestions in improving the manuscript.

Funding: This research received no external funding.

Conflicts of Interest: The authors declare no conflict of interest.

\section{Appendix A}

Table A1. Ordinary Least Squares Regression Models for 139 Countries from 2002-2014.

\begin{tabular}{|c|c|c|c|c|}
\hline & $\begin{array}{c}\text { Depth } \\
\text { [Lower Value Is a } \\
\text { Desired Outcome] }\end{array}$ & $\begin{array}{c}\text { Efficiency } \\
\text { [Lower Value Is a } \\
\text { Desired Outcome] }\end{array}$ & $\begin{array}{c}\text { Stability } \\
\text { [Higher Value Is a } \\
\text { Desired Outcome] }\end{array}$ & $\begin{array}{c}\text { Access } \\
\text { [Lower Value Is a } \\
\text { Desired Outcome] }\end{array}$ \\
\hline Political Stability & $\begin{array}{c}-0.0146 * \\
(0.0057)\end{array}$ & $\begin{array}{c}-0.0076^{* *} \\
(0.0028)\end{array}$ & $\begin{array}{c}0.0014 \\
(0.0015)\end{array}$ & $\begin{array}{c}0.0013 \\
(0.0009)\end{array}$ \\
\hline Regulatory Quality & $\begin{array}{l}-0.0131 \\
(0.0101)\end{array}$ & $\begin{array}{c}0.0067 \\
(0.0041)\end{array}$ & $\begin{array}{l}-0.0006 \\
(0.0021)\end{array}$ & $\begin{array}{c}0.0010 \\
(0.0010)\end{array}$ \\
\hline Rule of Law & $\begin{array}{c}0.0041 \\
(0.0111)\end{array}$ & $\begin{array}{c}0.0069 \\
(0.0055)\end{array}$ & $\begin{array}{c}0.0023 \\
(0.0022)\end{array}$ & $\begin{array}{l}-0.0007 \\
(0.0013)\end{array}$ \\
\hline Transition & $\begin{array}{c}1.5179 * * * \\
(0.2240)\end{array}$ & $\begin{array}{c}-0.3193^{* *} \\
(0.1119)\end{array}$ & $\begin{array}{c}-0.7814^{* * *} \\
(0.0510)\end{array}$ & $\begin{array}{c}-0.0880 * * * \\
(0.0246)\end{array}$ \\
\hline Developed & $\begin{array}{l}3.0022 * * \\
(0.9979)\end{array}$ & $\begin{array}{l}-0.7777 \\
(0.5107)\end{array}$ & $\begin{array}{l}0.6943 * * \\
(0.2194)\end{array}$ & $\begin{array}{l}-0.0569 \\
(0.1125)\end{array}$ \\
\hline $\mathrm{R}^{2}$ & 0.80 & 0.87 & 0.85 & 0.71 \\
\hline $\mathrm{N}$ & 1640 & 1646 & 1649 & 1605 \\
\hline
\end{tabular}

Notes: DVs logged; Standard errors clustered by country; Country and Year fixed effects. Development Level 1 omitted category; Two-tailed tests of significance; ${ }^{*} p<0.05,{ }^{* *} p<0.01,{ }^{* * *} p<0.001$. (s.e. are in brackets below the variable coefficient).

\section{References}

Acemoglu, Daron, and Simon Johnson. 2005. Unbundling institutions. Journal of Political Economy 113: 949-95. [CrossRef]

Admati, Anat, and Martin Hellwig. 2013. The Bankers' New Clothes. Princeton: Princeton University Press.

Admati, Anat, Peter DeMarzo, Martin Hellwig, and Paul Pfleiderer. 2014. Fallacies and irrelevant facts in the debate on capital regulation. In Central Banking at a Crossroads: Europe and Beyond 33-50. Edited by Charles Goodhart, Daniela Gabor, Jakob Vestegaard and Ismail Erturk. London: Anthem Press.

Ansell, Chris, and Allison Gash. 2008. Collaborative governance in theory and practice. Journal of Public Administration Research and Theory 18: 543-71. [CrossRef]

Bacchiega, Alberto, and Carlo Borzaga. 2001. Social enterprises as incentive structures: an economic analysis. In The Emergence of Social Enterprise. Edited by Carlo Borzaga and Jacque Defourny. London: Routledge, pp. 273-94.

Battilana, Julie, and Sylvia Dorado. 2010. Building sustainable hybrid organizations: The case of commercial microfinance organizations. Academy of Management Journal 53: 419-40. [CrossRef] 
Boushey, Heather, Ryan Nunn, and Jay Shambaugh, eds. 2019. Recession Ready: Fiscal Policies to Stabilize the American Economy. Washington, DC: Brookings Institute.

Box, George E., and Gwilym M. Jenkins. 1976. Time Series Analysis, Control, and Forecasting. San Francisco: Holden-Day.

Brown, James, Gustav Martinsson, and Bruce Petersen. 2013. Law, stock markets, and innovation. Journal of Finance 68: 1517-49. [CrossRef]

Brown, James R., J. Anthony Cookson, and Heimer Rawley. 2017. Law and finance matter: Lessons from externally imposed courts. Review of Financial Studies 30: 1019-51. [CrossRef]

Cama, Giampiero, and Giovan Pittaluga. 1999. Central banks and democracy. Rivista Internazionale Di Scienze Sociali 107: 235-77.

Cecchetti, Stephen G., and Kermit L. Schoenholtz. 2011. Central Banks in the World Today. New York: McGraw-Hill Companies, Inc.

Čihák, Martin, Ash Demirgüç-Kunt, Erik Feyen, and Ross Levine. 2012. Benchmarking Financial Systems around the World. World Bank Policy Research Working Paper 617. Washington, DC: World Bank.

Demirgüç-Kunt, Asli, and Ross Levine. 2008. Finance, Financial Sector Policies, and Long-Run Growth. Washington, DC: The World Bank.

De Souza Briggs, Xavier. 2008. Democracy as Problem-Solving. Cambridge: MIT Press.

Fabozzi, Frank, Edwin Neave, and Guofu Zhou. 2012. Financial Economics. Hoboken: John Wiley and Sons.

Gupta, Abhishek. 2013. Environment and PEST analysis: An approach to the external business environment. International Journal of Modern Social Sciences 2: 34-43.

Hahn, Robert W., and Cass R. Sunstein. 2002. A new executive order for improving federal regulation? Deeper and wider cost-benefit analysis. University of Pennsylvania Law Review 150: 1489-552. [CrossRef]

Hannan, Michael T., and John Freeman. 1989. Organizations and social structure. Organizational Ecology, 3-27.

Hassin, Ahmed. 2010. Effective diagnosis in organizational change management. Journal of Business Systems, Governance E Ethics 5. [CrossRef]

Heclo, Hugh. 1987. Issue networks and the American establishment. In The New American Political System 1990. Edited by Anthony King. Washington, DC: American Enterprise Institute.

Johns, Gary. 2006. The essential impact of context on organizational behavior. Academy of Management Review 31: 396-408. [CrossRef]

Katz, Daniel, and Robert L. Kahn. 1966. The Social Psychology of Organizations. New York: Wiley.

Kaufmann, Daniel, and Aart Kraay. 2007. Spring. Governance indicators: Where are we, where should we be going? The World Bank Research Observer 23: 1-30. [CrossRef]

Kaufmann, Daniel, Aart Kraay, and Massimo Mastruzzi. 2010. The Worldwide Governance Indicators-Methodology and Analytical Issues. The World Bank Policy Research Working Paper, 5430. Available online: http://papers.ssrn.com/sol3/papers.cfm?abstract_id=1682130 (accessed on 15 August 2019).

Landow, Paul, and Carol Ebdon. 2012. Public-private partnerships, public authorities, and democratic governance. Public Productivity and Management Review 35: 727-52. [CrossRef]

Levine, Ross. 2005. Finance and growth: Theory and evidence. In Handbook of Economic Growth. Edited by Philippe Aghion and Steven Durlauf. Amsterdam: North-Holland, pp. 865-934.

Lijphart, Arend. 2012. Patterns of Democracy: Government Forms and Performance in Thirty-Six Countries. Connecticut New Haven: Yale University Press.

Lo, Andrew W. 2012. Reading about the financial crisis: A twenty-one-book review. Journal of Economic Literature 50: 151-78. [CrossRef]

Long, Norton E. 1949. Power and administration. Public Administration Review 9: 257-64. [CrossRef]

Maimbo, Samuel M., and Martin Melecky. 2014. Financial Sector Policy in Practice: Benchmarking Financial Sector Strategies around the World. Washington, DC: The World Bank.

Melecky, Martin, and Anca Maria Podpiera. 2018. Financial Sector Strategies and Financial Sector Outcomes: Do the Strategies Perform? (English). Policy Research Working Paper. no. WPS 8315. Washington, DC: World Bank Group, Available online: http://documents.worldbank.org/curated/en/731031516722333398/Financial-sectorstrategies-and-financial-sector-outcomes-do-the-strategies-perform (accessed on 15 August 2019).

Mishkin, Frederic S., and Stanley Eakins. 2012. Financial Markets and Institutions, 7th ed. Upper New Jersey River: Prentice-Hall.

North, Douglas C. 1981. Structure and Change in Economic History. New York: W.W. Norton and Company. 
North, Douglas C. 1990. Institutions, Institutional Change, and Economic Performance. Cambridge: Cambridge University Press.

North, Douglas C., and R. P. Thomas. 1973. The Rise of the Western World: A New Economic History. Cambridge: Cambridge University Press.

O'Toole, Lawrence J., Jr., and Kenneth J. Meier. 2015. Public management, context, and performance: In quest of a more general theory. Journal of Public Administration Research and Theory 25: 237-56. [CrossRef]

Pfeffer, Jeffrey, and Gerald R. Salancik. 1978. The External Control of Organizations: A Resource Dependence Perspective. New York: Harper \& Row.

Pierson, Paul. 2004. Politics in Time: History, Institutions, and Social Analysis. Princeton: Princeton University Press.

Scott, W. Richard. 2003. Organizations: Rational, Natural, and Open Systems, 5th ed. Stanford and Upper Saddle River: Prentice-Hall.

Sikken, Bernd Jan, and Jakob de Haan. 1998. Budget Deficits, Monetization, and Central-Bank Independence in Developing Countries. Oxford Economic Papers 50: 493-511. Available online: http://www.jstor.org/stable/ 3488584 (accessed on 15 August 2019). [CrossRef]

Song, Fenghua, and Anjan Thakor. 2012. Notes on Financial System Development and Political Intervention. No. 6350 Policy Research Working Paper. New York: The World Bank.

Stringham, Edward. 2002. The emergence of the London Stock Exchange as a self-policing club. Journal of Private Enterprise 17: 1-19.

Stringham, Edward. 2003. The extralegal development of securities trading in seventeenth-century Amsterdam. Quarterly Review of Economics and Finance 43: 321-44. [CrossRef]

Ter-Mkrtchyan, Ani. 2018. The functions of central banks: Mega-regulators on a continuum? Paper presented at Mid-West Political Science Association Annual Meeting, Chicago, IL, USA, April 5-7.

Thompson, James D. 1967. Organizations in Action. Social Science Bases of Administrative Theory. New York: McGraw Hill.

Tracey, Paul, Nelson Phillips, and Owen Jarvis. 2011. Bridging institutional entrepreneurship and the creation of new organizational forms: a multilevel model. Organization Science 22: 60-80. [CrossRef]

U.S. Department of the Treasury. 2017. A Financial System that Creates Economic Opportunities: Banks and Credit Unions; Washington, DC: U.S. Government Printing Office.

United Nations. 2014. World Economic Situation and Prospects (WESP)—2014 Country Classification. Available online: https://www.un.org/en/development/desa/policy/wesp/wesp_current/2014wesp_country_ classification.pdf (accessed on 15 August 2019).

Velleman, Paul F., and David C. Hoaglin. 1981. Applications, Basics, and Computing of Exploratory Data Analysis. Duxbury: Duxbury Press.

Voiculet, Alina, Nicoleta Belu, Denisa Elena Parpandel, and Ionela Carmen Rizea. 2010. The Impact of the External Environment on Organizational Development Strategy. Munch: mpra.ub.uni-muenchen.de.

Wakita, Shigeru. 2001. Efficiency of the Dojima rice futures market in Tokugawa-period Japan. Journal of Banking and Finance 25: 535-54. [CrossRef]

World Bank. 2018. Global Financial Development Database 2017/2018. Available online: https://www.worldbank. org/en/publication/gfdr/data/global-financial-development-database (accessed on 15 August 2019).

World Bank Group. 2019. Worldwide Governance Indicators (WGI) Project. Available online: https://info. worldbank.org/governance/wgi/\#home (accessed on 15 August 2019).

Zinovieva, Catherine G., Margarita V. Kuznetsova, Tatyana V. Dorfman, Pavel V. Limarev, and Juliya A. Limareva. 2016. Study of external and internal factors affecting enterprise stability. Advances in Systems Science and Applications 16: 62-71.

(C) 2020 by the authors. Licensee MDPI, Basel, Switzerland. This article is an open access article distributed under the terms and conditions of the Creative Commons Attribution (CC BY) license (http://creativecommons.org/licenses/by/4.0/). 